\title{
Effect of Different Edible Coatings on Postharvest Quality of Mandarin Orange (Citrus reticulata Blanco)
}

\author{
Barsha D.C. ${ }^{1}$, Monika Singh ${ }^{1}$, Prakash Khanal ${ }^{1 \bullet}$, Madan Pandey ${ }^{1}$, Rukmagat Pathak ${ }^{2}$ \\ ${ }^{1}$ Institute of Agriculture and Animal Science, Prithu Technical College, Lamahi, Dang Deukhuri, Nepal \\ ${ }^{2}$ Department of Horticulture, Institute of Agriculture and Animal Science, Paklihawa, Nepal \\ `Corresponding author email: prakash.khanal744@gmail.com
}

\begin{abstract}
Although Nepal produces a large amount of mandarin it faces huge postharvest losses due to improper postharvest practices. Treating fruits with different edible coatings can minimize postharvest losses. The experiment was carried out in the horticulture lab of Prithu Technical College, Dang, Nepal to evaluate the effects of different edible coating materials on the postharvest quality of mandarin. The experiment was laid in Complete Randomized Design (CRD) with three replications and seven treatments in each replication. Mandarins were coated with different edible coating materials i.e. paraffin wax $(100 \%, 75 \%$ and $50 \%)$, mustard oil, Aloe vera, turmeric paste and control (non-coated). After coating with different edible materials, mandarins were kept at ambient room conditions $\left(18 \pm 2^{\circ} \mathrm{C}\right.$ and $52.41 \pm 14.35 \%$ ). The lowest physiological loss in weight at 7, 14 and 21 days was recorded in mandarin coated with $75 \%$ paraffin wax which was $3.10 \%, 4.83 \%$ and $10.33 \%$, respectively. The highest titratable acidity $(0.68 \%)$, juice content $(46.33 \%)$ and marketable fruit percentage $(81.73 \%)$ were recorded in $75 \%$ paraffin wax. The highest total soluble solid (14.00 ${ }^{\circ}$ Brix) was recorded in control. Based on the result obtained from our research, it is suggested to use $75 \%$ paraffin wax for the storage of mandarin at ambient room conditions $\left(18 \pm 2^{\circ} \mathrm{C}\right.$ and $\left.52.41 \pm 14.35 \% \mathrm{RH}\right)$ as it gives a high percentage of marketable fruits and juice content and also minimizes the physiological loss in weight.

Keywords: coatings; edible; mandarin; postharvest; quality
\end{abstract}

\section{INTRODUCTION}

Mandarin orange (Citrus reticulata), belonging to the family Rutaceae, is one of the top citrus fruit grown in most countries. Nepal also produces a huge amount of mandarin in its hilly areas from east to west comprising fiftyfour districts (Rokaya et al., 2016). In Nepal, the three most important species of citrus are mandarin, sweet orange and acid lime in which mandarin, sweet orange and acid lime occupy first, second and third position, respectively, in term of area coverage and production (Pokhrel, 2011). Mandarin orange is one of the important and highly commercial citrus fruit of Nepal (Bhattarai \& Shah, 2017). In Nepal, mandarin types of citrus occupy $65.3 \%$ of the total citrus growing area and $67.2 \%$ of total citrus production (Pandey et al., 2017). In Nepal during the period of $2018 / 19$, the productive area of mandarin was 17,220 ha with the production of 177,381 metric tonnes (MoALD, 2020).

Although Nepal produces a large amount of mandarin, it faces the problems of high losses due to improper postharvest treatments amounting to about $20-25 \%$ of mandarin fruit (Rokaya et al., 2016; Bhattarai et al., 2013). It is more difficult to measure the qualitative losses of fresh fruits like caloric and nutritive value losses, acceptability and edibility losses than quantitative losses (Kader, 2005). It is necessary to minimize the postharvest losses and maximize the quantitative and qualitative parameters along with prolongation of the storage capacity of mandarin. Pathological breakdown, respiration loss and transpiration loss are the main causes of the loss in citrus during storage (Shahid \& Abbasi, 2011). The extension in the shelf life of a fruit depends on the control of processes related to ripening and senescence, moisture loss and decay development (Vanoli et al., 2015).

Checking the rate of transpiration, respiration, microbial infection and protecting membranes from disorganization are some ways to extend shelf life and minimize postharvest loss (Sahu, 2016). Among various postharvest treatments, the application of edible coating like oil, wax and chemical to 
fruits is receiving more attention as these coatings are capable of maintaining quality even in ordinary storage conditions (Bisen et al., 2012). Edible coating of fruits blocks the pores within the fruits, reduces respiration and creates a modified atmosphere which helps to improve postharvest quality (Kader, 2005). Edible coatings reduce respiration, improve textural quality, helps to retain volatile flavor, reduce microbial growth and protect from deterioration (Mahfoudhi et al., 2014).

Edible coatings maintain structural integrity and protect against mechanical damages (Dhall, 2013). Edible coatings improve the firmness and minimize the weight loss of mandarin as compared to uncoated (Navarro-Tarazaga \& Perez-Gago, 2006). Prolongation of shelf life and maintenance of the quality of mandarin fruit could be obtained by using different surface coatings than without using surface coatings (Joshi et al., 2020). For developing countries like Nepal which can't afford high technologies for the storage of mandarin, the application of edible coating can be the best alternative to minimize postharvest losses. Paraffin wax (100\%, 75\% and 50\%), mustard oil, Aloe vera and turmeric paste were used as coating materials in the study because they are easily available in Nepal and farmers can also afford them. Considering the above facts, this study was carried out to identify the appropriate coating materials for the storage of mandarin at ambient room conditions $\left(18 \pm 2^{\circ} \mathrm{C}\right.$ and $52.41 \pm 14.35 \% \mathrm{RH})$.

\section{METHODS}

\section{Experimental site}

The experiment was performed from $24^{\text {th }}$ January 2019 to $13^{\text {th }}$ February 2019 in the horticulture laboratory of Prithu Technical College, Lamahi, Dang Deukhuri of Nepal. Geographically, the experimental site is located at $27.99^{\circ} \mathrm{N}$ latitude, $82.30^{\circ} \mathrm{E}$ longitude and an elevation of 379.04 meters. The temperature and relative humidity were measured in degree Celsius $\left({ }^{\circ} \mathrm{C}\right)$ and percentage $(\%)$, respectively, by using a thermohygrometer as shown in Figure 1.

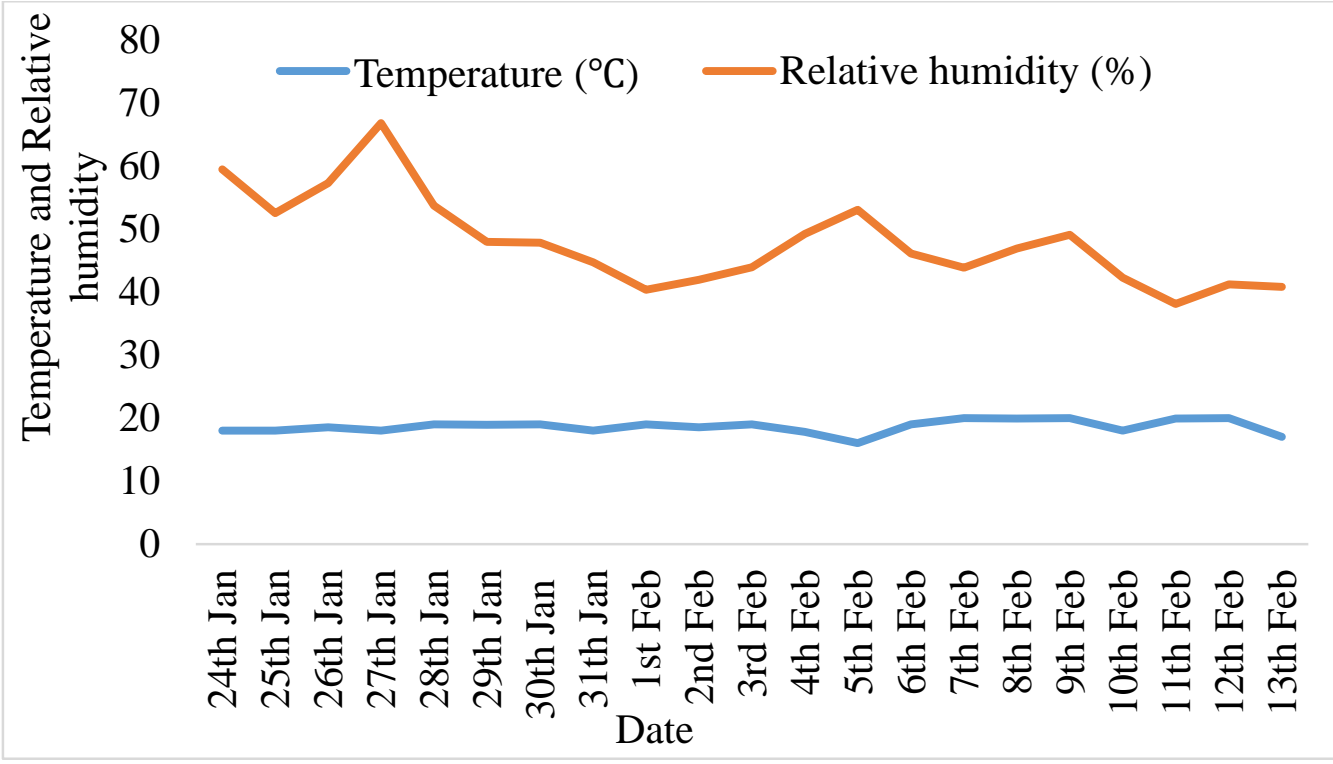

Figure 1. Temperature and relative humidity of the experimental room during the experimental period. 


\section{Experimental details and materials}

The experiment was laid out in Completely Randomized Design (CRD) with three replications having seven treatments in each replication. The mandarin oranges of local variety were collected from a local farmer of Salyan. The mandarin oranges were harvested at a mature stage. Mandarin oranges were sorted out to eliminate bruised, damaged, misshaped and punctured ones. Selected fruits having good quality were dipped in the beaker that contains a prepared concentration of different edible coating materials (Table 1). The mandarin oranges were kept for 5 minutes in the bucket and allowed to dry in fresh air. Then mandarin oranges were kept in the locally available tray in an open lab condition at ambient room conditions $\left(18 \pm 2^{\circ} \mathrm{C}\right.$ and $52.41 \pm 14.35 \% \mathrm{RH})$.

Table 1. Treatments used in the experiment

\begin{tabular}{llc}
\hline S.No. & Treatments & Time of treatments (minutes) \\
\hline 1 & 100\% Paraffin wax & 5 \\
2 & 75\% Paraffin wax & 5 \\
3 & 50\% Paraffin wax & 5 \\
4 & Mustard oil & 5 \\
5 & Aloe vera & 5 \\
6 & Turmeric paste & 5 \\
7 & Control (non-coated) & - \\
\hline
\end{tabular}

\section{Physiological loss in weight (PLW \%)}

Six mandarin oranges were selected randomly from each treatment to measure the physiological loss in weight in percentage. The mandarin oranges were weighed at seven days of interval (i.e. at 7, 14 and 21 days). PLW percentage was determined by using the following formula:

PLW $(\%)=\frac{\text { Initial weight-Final weight }}{\text { Initial weight }} \times 100 \%$

\section{Total soluble solids (TSS)}

The total soluble solids (TSS) was recorded in ${ }^{\circ}$ Brix by using a hand held

$$
\mathrm{TA}(\%)=\frac{\mathrm{NB} \times \mathrm{VB} \times \text { Milliequivalent factor of predominant acid }}{\text { Volume of mandarin juice sample }} \times 100 \%
$$

Where, $\mathrm{NB}=$ Normality of the base $(\mathrm{NaOH})$

$\mathrm{VB}=$ Volume of the base $(\mathrm{NaOH})$

Milliequivalent factor of predominant acid i.e citric acid is 0.0064 . refractometer on the first and last day of storage.

\section{Titratable acidity (TA)}

The acidity was estimated as per standard procedures of AOAC (2005). A total of $10 \mathrm{ml}$ of the clear juice of a fruit from each treatment was taken and titrated against standard $0.1 \mathrm{~N}$ of sodium hydroxide $(\mathrm{NaOH})$ solution using phenolphthalein as an indicator. Then the titratable acidity of the fruit was expressed in percentage using the following formula: 


\section{Juice content}

The juice was extracted by squeezing manually. The volume of juice was measured (ml/fruit) with the help of a measuring cylinder. The average juice percentage per fruit was calculated by the following formula:

Juice $(\%)=\frac{\text { Juice weight per fruit }}{\text { Individual fruit weight }} \times 100 \%$
Juice content is one of the important characters of mandarin oranges. Customers prefer those mandarin oranges which have more juice content and such mandarin oranges get high market price also. There is a decrease in the juice percentage of mandarin during the storage due to the moisture loss from the surface of fruits (Rokaya et al., 2016; Joshi et al., 2020). So to know the effect of different edible coatings on the juice content of the mandarin this parameter was observed.

\section{Marketable fruits percentage}

Marketable fruits percentage was calculated by using the following formula:

Marketable fruits percentage $=\frac{\text { Number of marketable fruits }}{\text { Total number of fruits }} \times 100 \%$

Marketable fruits were judged based on freshness, color, texture, aroma, taste and juice content.

\section{Statistical analysis}

The recorded data were analyzed by $\mathrm{R}$ studio. Data were subjected to analysis of variance (ANOVA) to determine the level of significance. The significant differences between treatments were determined using Duncan's Multiple Range Test (DMRT). The treatment means were compared by the Least Significant Difference (LSD) test at 5\% probability (Gomez \& Gomez, 1984).

\section{RESULTS AND DISCUSSION}

Effect of different edible coatings on physiological loss in weight (PLW \%)

Different edible coatings showed no significant effect on weight loss at storage (Table 2). However, $75 \%$ paraffin wax showed the best performance in terms of physiological loss in weight as it recorded the lowest physiological weight loss in 7, 14 and 21 days with $3.10 \%, 4.83 \%$ and $10.33 \%$, respectively, while the control recorded the highest physiological weight loss in 7, 14 and 21 days with $10.68 \%, 13.68 \%$ and $16.04 \%$, respectively. It might be because wax retarded the transpiration and respiration by closing lenticels and stomata of the cell wall of the fruit skin (Rokaya et al., 2016). Ahmad et al. (2013), Sahu (2016), Joshi et al.(2020) and Thapa et al. (2020) obtained minimum physiological weight losses in Kinnow fruit, custard apple, mandarin and sweet orange fruit, respectively, by wax treatment. As expected, the physiological loss in weight increased upon daily storage in all treatments (Table 2) due to the continuous loss of moisture caused by the transpiration and respiration process (Nath et al., 2011). 
Table 2. Effect of different postharvest treatments on physiological loss in weight (PLW \%)

\begin{tabular}{llll}
\hline \multirow{2}{*}{ Treatment } & \multicolumn{3}{c}{ Physiological loss in weight (\%) } \\
\cline { 2 - 4 } & Day 7 & Day 14 & Day 21 \\
\hline 100\% Paraffin wax & 6.18 & 8.17 & 11.50 \\
75\% Paraffin wax & 3.10 & 4.83 & 10.33 \\
50\% Paraffin wax & 5.30 & 7.40 & 10.82 \\
Mustard oil & 9.46 & 12.29 & 15.80 \\
Aloe vera & 8.97 & 11.01 & 15.70 \\
Turmeric paste & 8.03 & 10.16 & 15.63 \\
Control & 10.68 & 13.68 & 16.04 \\
\hline Mean & 7.39 & 9.64 & 13.68 \\
CV (\%) & 18.48 & 14.28 & 16.88 \\
LSD & NS & NS & NS \\
\hline
\end{tabular}

CV: Coefficient of variation, LSD: Least significant difference, NS: Non-significant.

Effect of different edible coatings on Total Soluble Solids (TSS)

Different edible coatings showed a significant effect on TSS (Table 3). The TSS was increased after storage in all the treatments that might be due to the conversion of starch and other insoluble carbohydrates into soluble solids (Purbiati \& Supriyanto, 2013). In terms of TSS, $50 \%$ paraffin wax was best because it recorded the lowest TSS $\left(10.00{ }^{\circ}\right.$ Brix $)$ which indicates the lowest increment in TSS value during storage. The highest TSS $\left(14.00{ }^{\circ}\right.$ Brix $)$ was recorded in control which indicates the rapid increment in TSS during storage. Other edible coating materials also showed a low increment in TSS value than control (Table 3). The low value of TSS in 50\% paraffin wax and other edible coating materials as compared to control during storage might be due to the creation of a physical barrier for transpiration losses and a modified atmosphere by coating materials (Jholgiker \& Reddy, 2007). The highest value of TSS in control might be due to the faster metabolic activities through respiration and transpiration in control as compared to treated with different coating materials (Rokaya et al., 2016). Similar observations were cited by Ladaniya et al. (2005), Deka et al. (2006), Rokaya et al. (2016) in various mandarin varieties and Thapa et al. (2020) in sweet oranges.

\section{Effect of different edible coatings on Titratable Acidity (TA)}

Different edible coatings showed a significant effect on titratable acidity (Table 3 ). The titratable acidity (TA) was decreased after the storage in all the treatments. The utilization of acid in the tricarboxylic acid cycle in respiration might have caused a decrease in TA (Paudel et al., 2019). Although there was a decrease in TA, 75\% paraffin wax was best in terms of TA because the highest retention of TA $(0.68 \%)$ was obtained in it followed by $0.57 \%$ in $100 \%$ paraffin wax. The lowest retention of TA $(0.32 \%)$ was obtained in the control. It might be due to less utilization of the acids in the respiration process during the storage in wax treated fruits whereas faster utilization of the acids in the respiration process during storage in the control (Bisen et al., 2012). Rokaya et al. (2016) and Khorram et al. (2017) obtained the lowest TA in the control as compared to treated with different 
coating materials in mandarin and Kinnow mandarin, respectively.

Table 3. Effect of different postharvest treatments on TSS and TA

\begin{tabular}{llllll}
\hline \multirow{2}{*}{ Treatments } & \multicolumn{2}{c}{ TSS $\left({ }^{\circ}\right.$ Brix $)$} & & TA $(\%)$ \\
\cline { 2 - 3 } \cline { 5 - 6 } & Initial value & Final value & & Initial value & Final value \\
\hline 100\% Paraffin wax & 9.66 & $11.16 \mathrm{bc}$ & & 1.42 & $0.57 \mathrm{ab}$ \\
75\% Paraffin wax & 9.66 & $11.53 \mathrm{bc}$ & & 1.42 & $0.68 \mathrm{a}$ \\
50\% Paraffin wax & 9.66 & $10.00 \mathrm{c}$ & & 1.42 & $0.51 \mathrm{abc}$ \\
Mustard oil & 9.66 & $11.90 \mathrm{~b}$ & & 1.42 & $0.36 \mathrm{~cd}$ \\
Aloevera & 9.66 & $11.46 \mathrm{bc}$ & & 1.42 & $0.41 \mathrm{bcd}$ \\
Turmeric paste & 9.66 & $12.10 \mathrm{~b}$ & & 1.42 & $0.45 \mathrm{bcd}$ \\
Control & 9.66 & $14.00 \mathrm{a}$ & & 1.42 & $0.32 \mathrm{~d}$ \\
\hline Mean & 9.66 & 11.73 & 1.42 & 0.47 \\
CV & & 5.13 & & 14.43 \\
LSD & & $1.36^{* * *}$ & & $0.32^{* * * *}$ \\
\hline
\end{tabular}

Means within the column followed by the same letter do not differ significantly by DMRT at 5\% level of significance, CV: Coefficient of variation, LSD: Least significant difference and $* * *=$ Significant at $P \leq 0.001$.

Table 4. Effect of different postharvest treatment in juice content and marketable fruit percentage

\begin{tabular}{lll}
\hline Treatments & Juice content $(\%)$ & Marketable fruit percentage \\
\hline 100\% Paraffin wax & $37.00 \mathrm{bc}$ & $71.64 \mathrm{ab}$ \\
75\% Paraffin wax & $46.33 \mathrm{a}$ & $81.73 \mathrm{a}$ \\
50\% Paraffin wax & $28.16 \mathrm{c}$ & $76.10 \mathrm{ab}$ \\
Mustard oil & $31.83 \mathrm{bc}$ & $69.55 \mathrm{ab}$ \\
Aloevera & $27.33 \mathrm{c}$ & $65.74 \mathrm{ab}$ \\
Turmeric paste & $43.66 \mathrm{ab}$ & $66.62 \mathrm{ab}$ \\
Control & $24.66 \mathrm{c}$ & $60.29 \mathrm{~b}$ \\
\hline Mean & 34.14 & 70.24 \\
CV $(\%)$ & 14.34 & 13.39 \\
LSD & $13.3^{* * *}$ & $16.07^{*}$ \\
\hline
\end{tabular}

Means within the column followed by the same letter do not differ significantly by DMRT at 5\% level of significance, CV: Coefficient of variation, LSD: Least significant difference, ***= Significant at $P \leq 0.001$ and $*=$ Significant at $P \leq 0.05$.

Effect of different edible coatings on juice content

Different edible coatings showed a significant effect on juice content (Table 4). Among various edible coating materials, $75 \%$ paraffin wax showed the best performance in terms of juice content as it recorded the maximum juice content (46.33\%) followed by $43.66 \%$ in turmeric paste while the lowest juice content $(24.66 \%)$ was recorded in the control. It might be because wax act as a barrier to check moisture loss from fruit (Joshi et al., 2020). Joshi et al. (2020) obtained more juice recovery in mandarin treated with wax as 
compared to others. Thapa et al. (2020) in sweet orange also obtained more juice content by wax treatment as compared to others.

\section{Effect of different edible coatings on marketable fruit percentage}

Different edible coatings showed a significant effect on marketable fruit percentage (Table 4). In terms of marketable fruit percentage, $75 \%$ paraffin wax was best as it recorded the highest marketable fruits percentage $(81.73 \%)$ followed by $50 \%$ paraffin wax $(76.10 \%)$. The lowest marketable fruit percentage was obtained in the control $(60.29 \%)$. It might be because wax act as a microbial inhibitor as well as a moisture inhibitor (Yadav et al., 2010).

\section{CONCLUSION}

From the experiment, it can be concluded that $75 \%$ paraffin wax recorded the lowest physiological weight loss in 7, 14 and 21 days with $3.10 \%, 4.83 \%$ and $10.33 \%$, respectively, highest TA $(0.68 \%)$, highest juice content $(46.33 \%)$ and marketable fruit percentage $(81.73 \%)$. Thus suggesting its use for the storage of mandarin at ambient room conditions $\left(18 \pm 2^{\circ} \mathrm{C}\right.$ and $\left.52.41 \pm 14.35 \% \mathrm{RH}\right)$. As far as we know, this is the first report on determining the best concentration of paraffin wax for highest effectivity in mandarin orange.

\section{ACKNOWLEDGMENT}

We express our sincere gratitude and warmest appreciation towards the Institute of Agriculture and Animal Science, Prithu Technical College, Tribhuvan University, Nepal for providing platform and support.

\section{Conflict of interest}

The authors declare no conflict of interest regarding the publication of this manuscript.

\section{REFERENCES}

Ahmad, M.S., Thakur, K.S., \& Siddiqui, M.W. (2013). Postharvest treatments for preserving quality of 'Kinnow' fruit under different storage conditions. Advances in Horticultural Science, 27(4): $152-158$.

AOAC. (2005). Official Methods of Analysis. Association of Official Analytical Chemists, Washington DC, USA.

Bhattarai, B.P., \& Shah, R. (2017). Effect of Different Packaging Materials on PostHarvest Status of Mandarin (Citrus reticuleta Blanco). Journal of Horticulture, 4: 218. DOI: 10.4172/23760354.1000218 .

Bhattarai, R.R., Rijal, R.K., \& Mishra, P. (2013). Post-harvest losses in mandarin orange: A case study of Dhankuta District Nepal. African Journal of Agricultural Research, 8(9): 763-767. DOI: https://doi.org/10.5897/AJAR12.1766.

Bisen, A., Pandey, S., \& Patel, N. (2012). Effect of skin coatings on prolonging shelflife of kagzi lime fruits (Citrus aurantifolia Swingle). Journal of Food Science and Technology, 49(6): 753-759. DOI: 10.1007/s13197-010-0214-y.

Deka, B.C., Sharma, S., \& Borah, S.C. (2006). Postharvest management practices for shelf life extension of Khasi mandarin. Indian. Journal of Horticulture, 63(3): 251-255.

Dhall, R.K. (2013). Advances in edible coatings for fresh fruits and vegetables: A review. Critical Reviews in Food and Nutrition, 53: 435-450. DOI: 10.1080/10408398.2010.541568.

Gomez, K.A., \& Gomez, A.A. (1984). Statistical procedures for agricultural research. International Rice Research Institute, Laguna, Phillipines.

Jholgiker, P., \& Reddy, B. (2007). Effect of different surface coating material on postharvest physiology of (Annona 
squamosa L.) fruits under ambient and zero energy cool chamber storage. Indian Journal of Horticulture, 64(1): 41-44.

Joshi, P., Ojha, B.R., and Kafle, A. (2020). Effect of Different Postharvest Treatments on Prolonging Shelf life of Citrus reticulata Blanco. Nepalese Horticulture, 14: 1-8. DOI: https://doi.org/10.3126/nh.v14i1.30603.

Kader, A. (2005). Increasing food availability and reducing postharvest losses of fresh produce. Acta Horticulturae, 682: 2169 2176.

DOI:

10.17660/ActaHortic.2005.682.296.

Khorram, F., Ramezanian, A., Mohammad, S., \& Hosseini, H. (2017). Effect of different edible coatings on postharvest quality of 'Kinnow' mandarin. Journal of Food Measurement and Characterization, 11: 1827-1833.

DOI: https://doi.org/10.1007/s11694-0179564-8.

Ladaniya, M.S., Singh, S., \& Mahalle, B. (2005). Sub-optimum low temperature storage of 'Nagpur'mandarin as influenced by wax coating and intermittent warming. Indian Journal of Horticulture, 62(1): 1-7.

Mahfoudhi, N., Chouaibi, M., \& Hamdi, S. (2014). Effectiveness of almond gum trees exudate as a novel edible coating for improving postharvest quality of tomato (Solanum lycopersicum L.) fruits. Food Science and Technology International, 20(1): 33-43. DOI: 10.1177/1082013212469617.

MoALD. (2020). Statistical Information on Nepalese Agriculture, Ministry of Agriculture and Livestock Development (MoALD), Singh Durbar, Kathmandu, Nepal.

Nath, A., Deka, B.C., Singh, A., Patel, R.K., Paul, D., Mishra, L.K., \& Ojha, H. (2011). Extension of shelf life of pear fruits using different packaging materials. Journal of Food Science and Technology, 49(5):
556-563. DOI: 10.1007/s13197-0110305-4.

Navarro-Tarazaga, M.L.L., \& Perez-Gago, M.B. (2006). Effect of edible coatings on quality of mandarins cv. Clemenules. Proceedings of the Florida State Horticultural Society. 119: 350-352.

Pandey, G., Basnet, S., Pant, B., Bhattarai, K., Gyawali, B., \& Tiwari, A. (2017). An Analysis of Vegetables and Fruits Production Scenario in Nepal. Asian Research Journal of Agriculture, 6(3): 110. DOI: 10.9734/ARJA/2017/36442.

Paudel, A., Baral, D., Acharya, H., \& Dhital, M. (2019). Effect of Post-Harvest Dipping and Various Packaging Materials on Quality Traits of Mandarin (Citrus reticulata Blanco.). Acta Chemica Malaysia, 3(2): 14-20. DOI: 10.2478/acmy-2019-0007.

Pokhrel, C.N. (2011). Analysis of market chain of mandarin in Nepal: A case of Lamjung district. A research project submitted to Van Hall Larenstein University of Applied Sciences.

Purbiati, T., \& Supriyanto, A. (2013). Effect of harvesting methods and storage temperature on shelf life of mandarin fruit cultivar 'Soe' from East Nusa Tenggara, Indonesia. Acta Horticulture, 989:149152.

Rokaya, P.R., Baral, D.R., Gautam, D.M., Shrestha, A.J., \& Paudyal, K.P. (2016). Effect of Postharvest Treatments on Quality and Shelf Life of Mandarin (Citrus reticulata Blanco). American Journal of Plant Sciences, 7: 1098-1105. DOI:

http://dx.doi.org/10.4236/ajps.2016.7710 5.

Sahu, B. (2016). Effect of different postharvest treatments on prolonging shelflife of sugar apple (Annona squamosa L.). M.Sc. Thesis, Indira Gandhi Krishi Vishwavidyalya, India.

Shahid, M.N., \& Abbasi, N.A. (2011). Effect 
of bee wax coatings on physiological changes in fruits of sweet orange $\mathrm{cv}$. "Blood Red." Sarhad Journal of Agriculture, 27(3): 385-394.

Thapa, S., Sapkota, S., \& Adhikari, D. (2020). Effect of different postharvest treatments on prolonging shelf life and maintaining quality of sweet orange (Citrus sinensis Osbeck.). Sustainability in Food and Agriculture, 1(2): 69-75. DOI: http://doi.org/10.26480/sfna.02.2020.69. 75.

Vanoli, M., Grassi, M., Buccheri, M., \& Rizzolo, A. (2015). Influence of edible coatings on postharvest physiology and quality of honeydew melon fruit (Cucumis melo L. inodorus). Advances in Horticultural Science, 29: 65-74. DOI: 10.13128/ahs-22683.

Yadav, M., Kumar, N., Singh, D.B., \& Singh, G.K. (2010). Effect of Postharvest Treatments on Shelf Life and Quality of Kinnow Mandarin. Indian Journal of Horticulture, 67: 243-248. 